\title{
Soham Gupta: Angst or Fiction?
}

Erschienen in: ANGST + | FEAR +

Von: Emily Doucet

Soham Gupta's Angst has been described as existing somewhere between fact and fiction. The series of twenty photographs was acquired by the Museum Folkwang in 2019 and featured in a recent exhibition. The images originated as part of a celebrated photobook, Angst, which was shortlisted for the Paris Photo-Aperture Foundation First Photobook Award and the Les Rencontres d'Arles Photo-Text Book Award. The design of the Folkwang exhibition visually poses a series of questions that have long preoccupied historians, theorists, and practitioners of photography: What is the relationship between photography and political subjectivity? How might an ethical relationship between photographer and photographed be defined? Gupta's glaringly lit nighttime portraits picturing individuals living under the Howrah bridge in his native city, Kolkata, have provoked a variety of critical responses, highlighting a kind of disciplinary angst over the critique of - and the historical relationship between - photography and representation.

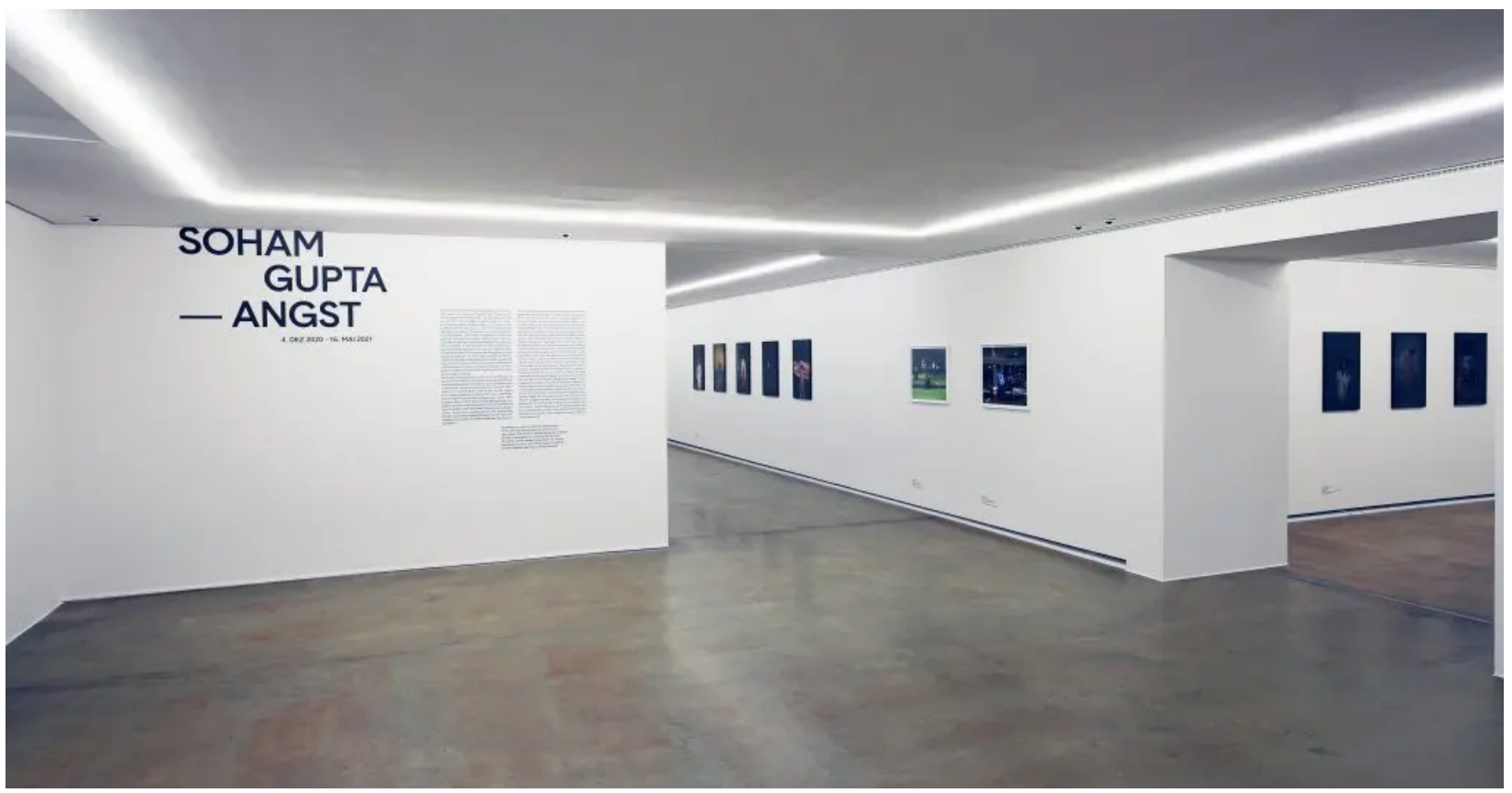

Figure 1: Installation view of Soham Gupta, Angst, at the Museum Folkwang, 4 December 2020 - 27 June 2021. Photocredit: Jens Nober/Museum Folkwang.

Reading through the reviews and press coverage on Gupta's photobook and photographs from this series, I noticed a common tic in writers conditioned to being critical of images of individuals in marginalized positions: Gupta isn't a 'voyeur' they said, but rather a 'storyteller.' The images weren't simply 'taken,' they were 'staged.'1 These 
responses contain a readymade caveat to the charge that Gupta's images of marginalized individuals could be considered exploitative because of the imbalance of power between Gupta's social position and that of his subjects. Internalizing this critique, responses to Gupta's work sometimes suggest that the way around this fraught relationship between photographer and photographed is to move away from 'facts' entirely, asserting instead the agency of the photographed individual as a willing participant in a theatrical scene. In an essay critical of the series written for the Photo Ethics Centre, Adira Thekkuveettil and Amarnath Praful suggest that Gupta hasn't been afforded the same critical approach that European or North American photographers have, and that, in the case of Gupta's Angst, the inequality in power relations between photographer and photographed "[...] is telling on both the artist and us as a society; we are habituated to flitting in and out of the lives of the marginalised, co-opting and scavenging parts of their stories while centring the narratives on ourselves."2

Both the critique and the praise of Gupta's work thus rest on the premise of the photographic image as inherently part of a story. The act of turning the figures in the photographs into characters in a narrative is variously politically ennobling or damning depending on your understanding of the photographer in relationship to his subjects. Likewise, words like 'theatrical' and 'dramaturgy' are used to describe Gupta's series in order to articulate this relationship. The fact that the individuals pictured are, according to Gupta, playing a part, is acknowledged by some as rescuing a photographic project that otherwise would be exploitative. Other reviewers affirm Gupta's work based on the proposition that he has conversed at length with these individuals and thereby secured enough of a rapport to represent them humanely and equitably.

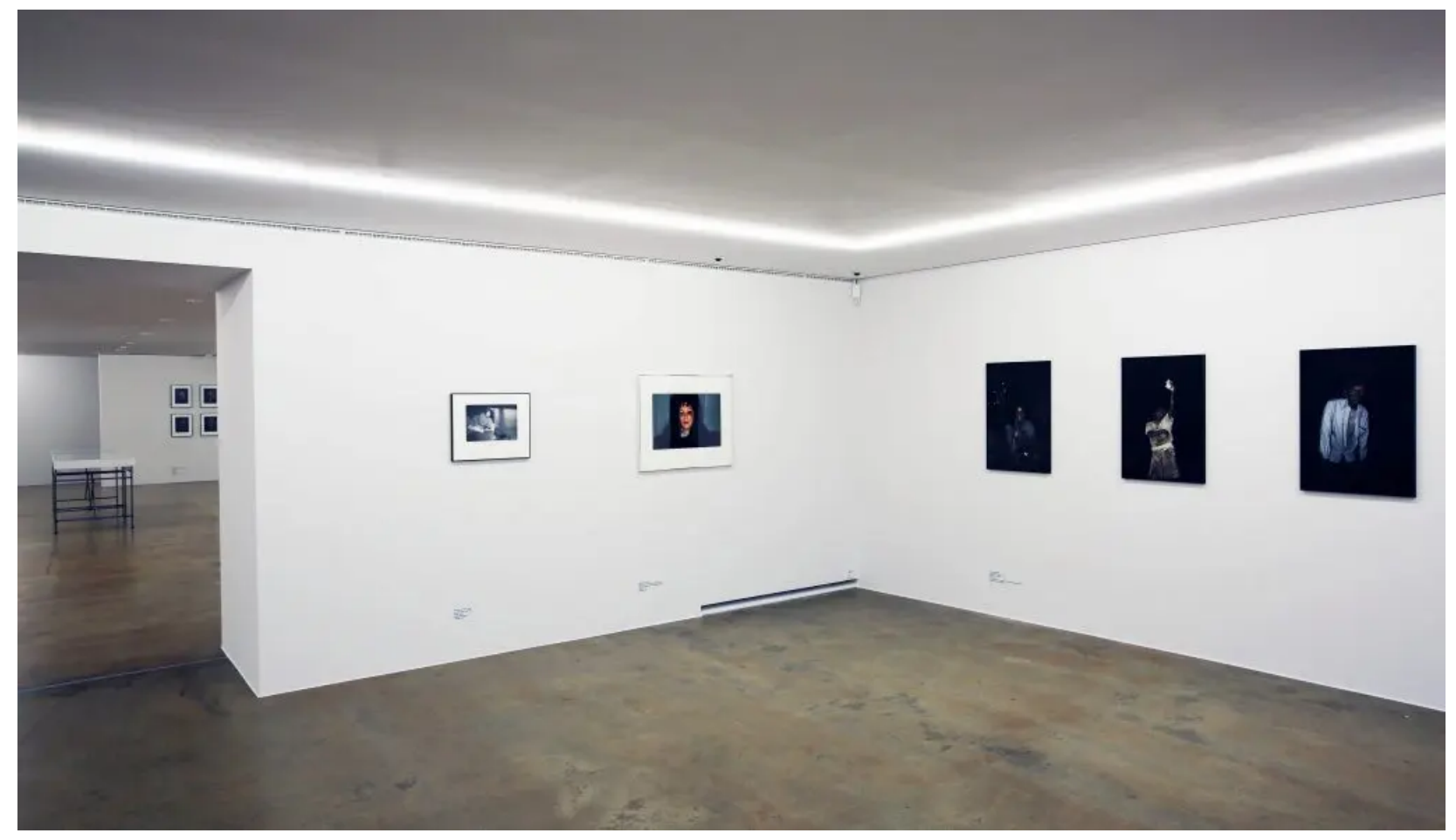

Figure 2: Installation view of Soham Gupta, Angst, at the Museum Folkwang, 4 December 2020 - 27 June 2021. Photocredit: Jens Nober/Museum Folkwang. 
The installation of these works at the Museum Folkwang does more than take a side of this argument; instead, the exhibition visually demonstrates the prominence of these questions in the history of photography. Exhibition viewers see Gupta immersed in the photographic documentary (and photo book) tradition that he himself has claimed. We experience his large-scale spectacularly lit, inky prints surrounded by works by photographers such as Alan Sekula, Irving Penn, and Diane Arbus, among others comparative works which dwell upon, or provoke a reconsideration of, the complex and politicized power relations between photographer and photographed.

These comparisons beg the question: Is the supposed dichotomy between fact and fiction all that useful anymore when thinking about the politics of photography? The documentary filmmaker Brett Story has written recently of the complex relationship between the notion of 'story' in documentary film and the concept of 'property.' While the author is discussing narrative filmmaking more specifically, the intersection of these two concepts seems to me to be central to the debate around Gupta's images. As Story reflects on her own non-narrative documentary film-making practice,

a story - as we have come to use that term - belongs, confers rights, can be exchanged, and is invested with value. A story is mine or it's yours. Stories are bound, if not always by a beginning, a middle, and an end, then by some variation of this structural edifice. We trade them or share them or, increasingly, we sell them. Story's resemblance to property, in these ways and others, is instructive. ${ }^{3}$

In the coverage of Gupta's series, 'story' is likewise employed as a foil for photography's truth problem, evoking the property relations that Story describes as characteristic of the narrative form. Either Gupta collaborates with his subjects on the creation of a new character for them to play, or he 'takes' their story away from them. But is the notion of 'story' and its attendant narrative structures really the political framework within which we want to understand such images? 


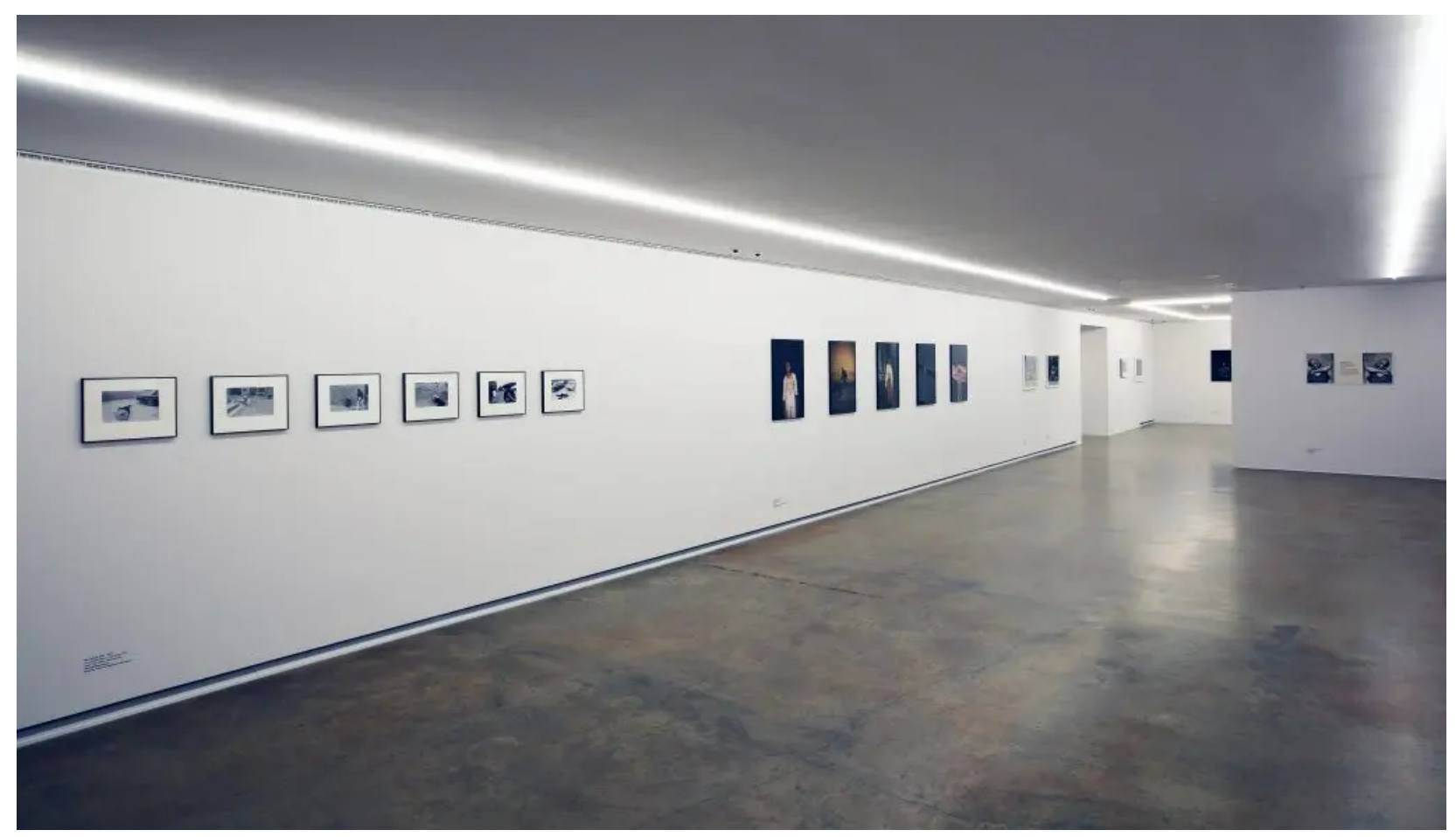

Figure 3: Installation view of Soham Gupta, Angst, at the Museum Folkwang, 4 December 2020 - 27 June 2021. Photocredit: Jens Nober/Museum Folkwang.

This is not a new question in the history of documentary photography. For example, Alan Sekula has offered the term "anti-photojournalism", conceptualized in relation to his response to the 1999 anti-World Trade Organization protests in his work Waiting for Tear Gas, 1999-2000. The term describes Sekula's explicit avoidance of moments of dramatic tension or violence in favour of working "against the grain" of traditional photojournalism (and the history of photojournalism that has often precluded a radical politics). ${ }^{4}$ The exhibition at the Folkwang foregrounds such comparisons, offering a juxtaposition of Alan Sekula's Two, Three, Many (terrorism) alongside Gupta's figures. In Sekula's photographs, a figure playing the part of a guerilla fighter has brought the Vietnam war into the driveways of American suburbia, just like the images of the war streaming into American homes. From within an expanse of velvety blankness the theatre of Gupta's images is harder to decipher, and precisely who is directing the scene (and to what end) is left unclear. Gupta seems to suggest baldly: these are actors, not subjects. 


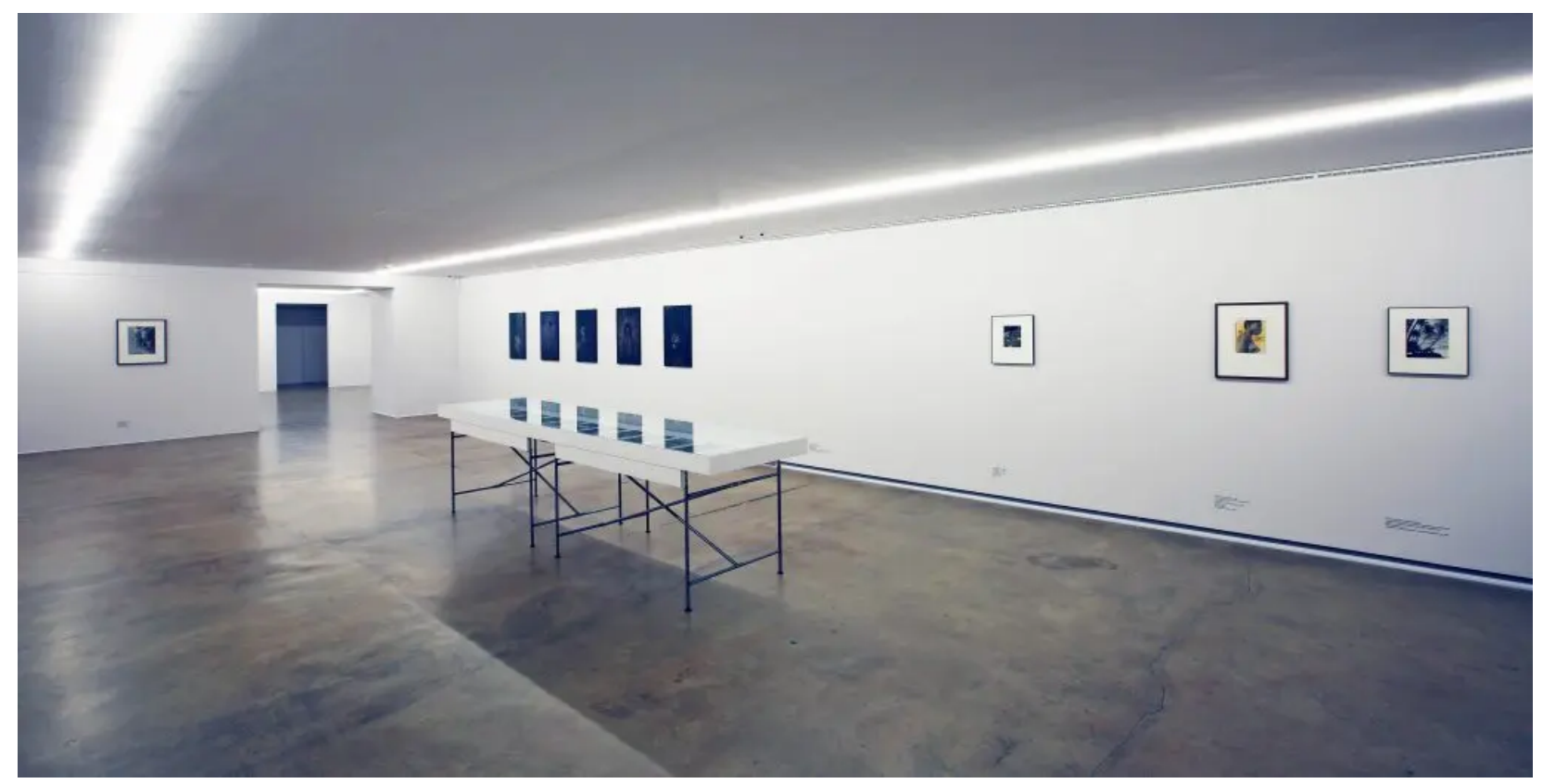

Figure 4: Installation view of Soham Gupta, Angst, at the Museum Folkwang, 4 December 2020 - 27 June 2021. Photocredit: Jens Nober/Museum Folkwang.

Like many of Sekula's works, Gupta's series initially gained prominence as a photobook. The large-scale prints of the installation at the Folkwang are presented apart from the text accompanying the images in the book, which is primarily a stream of consciousness narrative featuring vignettes and memories of encounters from the city of Kolkata. In the museum exhibition, the images are instead set afloat within the history of North American and European photography, an interesting curatorial formulation which reflects not only on the history of documentary photography but also on the collecting practices of the museum. The installation considers Gupta's professed influences but also offers some more challenging comparisons. In doing so, the exhibition offers viewers an opportunity to contemplate the collection and the history of documentary photography more broadly. Productively, we are left with more questions than answers.

\section{References}

1. Soham Gupta has compiled much of the coverage on the book on his website. Soham Gupta, "Essays and Reviews", https://soham-gupta.com/essays-reviews.

2. Adira Thekkuveettil and Amarnath Praful, "Field Notes on Othering: A Critique of Soham Gupta's Photobook 'Angst'”, August 15, 2019, https://www.photoethics.org/content/2019/8/15/field-notes-on-othering-a-critiqueof-soham-guptas-photobook-angst.

3. Brett Story, "How Does It End: Story and the Property Form", World Records Journal, volume 5 (2021): Article 11. https://vols.worldrecordsjournal.org/05/11? fbclid=IwAR0bwOgWF0ZXOt4JCpNaataBzgH3C0IDxjpkzn0f7FGsjRjMdX5AT0PT caM\#source14. 
4. "Against the grain" is a reference to Sekula's important 1984 collection of essays and photoworks, Photography Against the Grain: Essays and Photoworks 19731983. Stephanie Schwartz argues that Sekula works against not only the aesthetics of photojournalism but also the history of photojournalism which has neglected the traditions of documentary photography in radical left political movements. See Stephanie Schwartz, "Anti-Photojournalism: Working Against the Grain", in Stephanie Schwartz, In Focus: Waiting for Tear Gas 1999-2000 by Allan Sekula. Tate Research Publication, 2016.

https://www.tate.org.uk/research/publications/in-focus/waiting-for-tear-gas-allansekula/anti-photojournalism.

SUGGESTED CITATION: Doucet, Emily: Soham Gupta: Angst or Fiction?, In: KWIBLOG, [https://blog.kulturwissenschaften.de/soham-gupta-angst-or-fiction/], 05.07.2021

DOI: https://doi.org/10.37189/kwi-blog/20210705-0830 
Dieser Text wird via DuEPublico, dem Dokumenten- und Publikationsserver der Universität Duisburg-Essen, zur Verfügung gestellt. Die hier veröffentlichte Version der E-Publikation kann von einer eventuell ebenfalls veröffentlichten Verlagsversion abweichen.

DOI: $\quad$ 10.37189/kwi-blog/20210705-0830

URN: urn:nbn:de:hbz:464-20210705-103250-7 